\title{
A diplomacia brasileira em crise
}

A entrevista que apresentamos aqui foi concedida por Débora Santana, professora da Universidade de Fortaleza (UNIFOR), Mônica Dias Martins, professora da Universidade Estadual do Ceará (UECE), e Luís Gustavo Guerreiro, doutorando do Programa de PósGraduação em Políticas Públicas da UECE, para o apresentador do programa Rádio Debate, transmitido pela Rádio Universitária FM da Universidade Federal do Ceará, em 17 de setembro de 2019.

Pedro Victor: Bom dia! Hoje é terça feira, dia 17 de setembro de 2019. Eu sou Pedro Victor e está no ar mais um Rádio Debate. Os brasileiros nunca ouviram falar tanto em crise diplomática como nos quase nove meses que se completam do novo governo federal. Fatos sucessivos vêm tornando essa crise cumulativa nesse período. Representantes do governo e o próprio presidente Jair Bolsonaro protagonizaram atritos com países da Liga Árabe, com países europeus - como França, Noruega, Dinamarca e Alemanha -, e com nossos vizinhos da América Latina - Argentina, Colômbia e Chile. Mas, afinal, há precedentes na história que revelem as graves crises diplomáticas vivenciadas pelo Brasil? Que consequências a crise atual pode trazer para o país e para nós, brasileiros? Para não falar só dos erros e aprender com o passado, em que momentos fomos destaque e referência mundial na diplomacia?

É o que vamos tentar responder na Rádio Debate de hoje. Nosso programa conta com a presença de Débora Santana, advogada, professora do curso de especialização em Direito Internacional da Universidade de Fortaleza (UNIFOR) e doutora pela D'AixMarseille Université, na França; com Mônica Martins, professora da Universidade Estadual do Ceará (UECE) e doutora em Sociologia pelo Programa de Pós-Graduação em Sociologia da Universidade Federal do Ceará (UFC); e Gustavo Guerreiro, doutorando em Políticas Públicas pela Universidade Estadual do Ceará (UECE). Mônica e Gustavo integram o grupo de pesquisa Observatório das Nacionalidades (ON) e são editores da revista Tensões Mundiais. 
No final de agosto, o diplomata e ex-ministro Rubens Ricupero disse, em entrevista ao jornal $O$ Globo, que acha muito difícil o Brasil recuperar sua imagem no exterior. Ele acredita que essa é a pior crise de imagem do país nos últimos 50 anos. Vocês concordam com a avaliação de Ricupero?

Mônica Martins: Bom dia, ouvintes; bom dia, Gustavo; bom dia, Débora; bom dia, Pedro! É um prazer estar aqui de novo. Trouxemos um exemplar de Tensões Mundiais com a nossa última entrevista com Bas'llele' Malomalo ${ }^{1}$ e Camila Costa, ${ }^{2}$ quando organizamos, em maio de 2018, o VI Encontro Tensões Mundiais que tratava justamente da política externa brasileira. Já naquele momento, o ON tinha algumas preocupações relacionadas com a mudança de eixo da política no governo golpista do Michel Temer. Então, a gente refletia sobre a tradição diplomática do Brasil, que vinha de longa data e inclui o privilégio de ter a fala do nosso presidente como abertura da sessão da ONU, anualmente. Isso não é pouca coisa. Foi resultado de uma conquista da diplomacia brasileira, que, mesmo em momentos mais difíceis, como foram os 20 anos da ditadura civil-militar, conseguiu manter uma relação bastante tranquila, por exemplo, com Angola, que saia de uma luta de libertação nacional apoiada pelo partido comunista de Cuba e da União Soviética...

Pedro Victor: Desde a ditadura militar havia uma boa relação com países que se diziam comunistas?

Mônica Martins: Sim, claro, porque em termos da diplomacia brasileira conta a tradição do Itamaraty, reconhecido como um dos grandes formadores de diplomatas. Não é à toa que nós recebemos pessoas de todo o mundo que vêm estudar no Brasil. É que a política interna, por mais complicada que sejam nossas crises e desavenças, não deve prejudicar a projeção da nação brasileira e o nosso contato com a comunidade de nações, com a comunidade internacional. É também uma visão pragmática a de que política se faz, inclusive, com uma negociação entre países que têm

\footnotetext{
1 Bas'llele Malomalo é professor do curso de graduação em Relações Internacionais e do Mestrado Interdisciplinar em Humanidades da Universidade de Integração Internacional da Lusofonia Afro-Brasileira (UNILAB), na Bahia. 2 Camila Costa é pesquisadora do Observatório das Nacionalidades e foi editora executiva de Tensões Mundiais.
} 
alguma coisa a oferecer ao outro. Então, para dar continuidade ao exemplo que usei, Angola significava a abertura de um amplo mercado e, mesmo contrariando a ditadura portuguesa, na época, o governo militar reconheceu a independência da Angola. Aliás, fomos o primeiro país do mundo a reconhecer o governo comunista de Angola, saído de uma luta de libertação. Eu não considero que nós jogamos a toalha, nem concordo integralmente com as palavras de Ricupero de que a nossa imagem está comprometida para sempre e que vai ser difícil recuperar. Não. Nós estamos na disputa. A sociedade brasileira está firme e ela reconhece o prestígio da nossa diplomacia. Agora a disputa se dá, porque somos um país que tem uma forte visibilidade para o imperialismo neoliberal. Os Estados Unidos, especificamente, pretendem que ainda sejamos o quintal deles, pretendem que continuemos com uma política externa dirigida por eles e para eles. No entanto, ao mesmo tempo, experimentamos, por alguns anos, um prestígio internacional que nós não esquecemos, porque aumentou a autoestima do povo brasileiro, não só do diplomata, do governante, do parlamentar. O povo brasileiro sentiu que a gente estava construindo uma contra-hegemonia, construindo alguma coisa que era uma cooperação, e isso não é esquecido facilmente. Considero que não é perdido, nós estamos na disputa.

Pedro Victor: Acredito que essa é a pior crise de imagem do país nos últimos 50 anos... você concorda, professora Débora?

Débora Santana: Bom, depois dessa aula da professa Mônica, que resumiu basicamente o nosso contexto atual, eu entendo que as palavras dele [do Ricupero] são um pouco drásticas, muito embora elas não deixem de ser verdadeiras. Nós viemos de um período em que a diplomacia, por muito tempo, foi a diplomacia da paz. Então, depois da redemocratização, os governos tentaram fazer com que a imagem do Brasil lá fora fosse uma imagem realmente de prestígio. Nós alcançamos uma linha de visibilidade internacional e nos aproximamos de países até para fazer frente a países do Primeiro Mundo, tanto na área comercial, como também especificamente na Organização das Nações Unidas (ONU). Temos 
a formação do BRICS, ${ }^{3}$ a aproximação com os países da África dentro da Organização Mundial do Comércio (OMC), que basicamente foi a minha área de estudo desde o mestrado... O Brasil, junto com a Índia e os demais países, fizeram frente aos Estados Unidos e à União Europeia (EU). Então, a gente tem um papel, sim, de linha de frente mesmo na política internacional. Nesse cenário, não temos, vamos dizer assim, o peso de outros países em termos econômicos, mas o temos em matéria de diplomacia. Nisso, saudamos o Itamaraty, porque nós temos um pessoal do mais alto nível e qualidade e, realmente, dói meu coração quando escuto que o presidente indica um filho dele para embaixador nos Estados Unidos, quando nós sabemos o quanto vários estudantes estão se dedicando ao concurso do Itamaraty...

Pedro Victor: Um absurdo a concorrência para passar no concurso do Itamaraty. É zero, pois você concorre contra você mesmo, porque sobram vagas ao final.

Débora Santana: Realmente, dói meu coração escutar isso pelo fato de que nós precisamos de diplomatas qualificados. Nós tivemos várias frentes, não só a ONU e a OMC; em outras organizações internacionais, são os nossos representantes que têm feito um papel importantíssimo lá fora. Então, eu entendo [as palavras do Ricupero] como drásticas, mas não deixam de ser verdadeiras, porque existe uma crise.

Vamos colocando o pé no chão: ela [a crise] tem se agravado pelos pronunciamentos do nosso chefe de Estado; então são pronunciamentos irresponsáveis e infantis, eu diria, e que agravam as relações brasileiras. Inclusive, vou mais além, agravam as relações econômicas. Se a pauta desse governo é a economia, nós estamos correndo riscos altíssimos de ir por água abaixo, porque qual é o país que vai investir no Estado em que o presidente diz uma coisa em uma hora e, em outra hora, volta atrás? Em que o presidente simplesmente troca farpas, fofocas de cabelereiro com esposa de presidente de uma república ou questão assim em relação a ex-presidente de outro país? Com o que nós estamos

3 BRICS é a sigla que designa um agrupamento de países de mercado emergente em relação ao seu desenvolvimento econômico. Esse agrupamento é composto por Brasil, Rússia, Índia, China e África do Sul. 
gastando tempo? Então, isso [as relações brasileiras] tem se agravado por pronunciamentos do nosso presidente especificamente.

E só complementando a professora Mônica, para passar a palavra para o Gustavo, o que acontece é que o Brasil na ONU sempre foi um dos primeiros países a abrir [o discurso na sessão da Assembleia Geral], a aderir à Liga das Nações Unidas. Ele esteve presente na Conferência de São Francisco. ${ }^{4}$ Nós estivemos lá, mesmo na ditadura militar, com um estremecimento da diplomacia, estivemos lá. Inclusive, o último presidente da ditadura, o João Figueiredo, ele também fez seu pronunciamento na Assembleia Geral da ONU. Então, nossos representantes no passado estavam ali, abrindo os trabalhos da Assembleia das Nações Unidas, em que nós tivemos sempre um papel de destaque.

Anteontem estava escutando, na rádio, que o porta-voz do governo disse que o pronunciamento do presidente seria muito claro: ele iria tocar na questão da soberania. A soberania especificamente, porque nos últimos acontecimentos se relata a [questão do desmatamento e dos incêndios na] Amazônia, mas nós tivemos sempre [esse tema] nesses pronunciamentos. Se a gente fizer um estudo retrospectivo, foram mencionadas questões sociais e do clima. Nos últimos governos, o clima foi pauta dos próprios pronunciamentos da ONU; o nosso papel sempre foi de uma diplomacia da paz, de convivência com os demais Estados. Então, pronunciamentos que agravem nossas relações diplomáticas com outros países repercutem diretamente na nossa economia. Daí porque eu entendo que não seja tão drástico, mas que realmente apresenta um perigo, pois qual país vai querer investir em um Estado que não lhe demonstra nem segurança jurídica, nem política e que, a todo momento, acaba havendo estremecimento e picuinha? Realmente, para mim, são alguns discursos mesmos, até mesmo infantis, que não caberiam a um chefe de Estado.

4 A Conferência das Nações Unidas sobre Organização Internacional (UNCIO, na sigla em inglês) foi uma convenção de delegados de 51 nações aliadas que aconteceu de 25 de abril de 1945 a 26 de junho de 1945, em São Francisco, nos Estados Unidos. Nessa convenção, os delegados revisaram e reescreveram os acordos de Dumbarton Oaks, e ela resultou na criação da Carta das Nações Unidas. 
Pedro Victor: Gustavo, no início do programa eu fiz um pequeno histórico, um cronograma aqui sobre uns atritos internacionais. Vamos problematizar um pouquinho cada um deles. Qual o primeiro atrito que você gostaria de destacar e as consequências disso para o Brasil e para o mercado brasileiro?

Gustavo Guerreiro: Olha, é um desafio escolher um deles, mas...

Pedro Victor: O primeiro basicamente foram os médicos cubanos, não é mesmo?

Gustavo Guerreiro: Então, o atual governo tem uma obsessão, uma tal perseguição aos comunistas, no interior do país, que é como se a gente estivesse realmente vivendo essa fase do processo histórico, o que nos causa estranheza. Acredito que essa tenha sido uma das medidas que ele tomou para justificar os abusos que esse governo comete, mas você tem várias questões e aí eu queria, não seguindo essa ordem cronológica, destacar a questão desse contencioso com a França, as consequências econômicas que a professora Débora colocou com muita propriedade.

O processo diplomático tem consequências também econômicas muito importantes para o país e, nesse caso, destacaria, sem que uma questão esteja separada da outra, os incêndios da Amazônia e o acordo comercial do Brasil com a UE, que tem, em um dos seus pontos mais delicados, a questão ambiental. Daí, você remete à vinda de um representante do governo dos Estados Unidos ao Brasil, quando ele falou que o acordo comercial entre Brasil e UE tinha "pílulas de veneno". ${ }^{5}$ Ou seja, dando um recado: o acordo foi assinado pelo governo Bolsonaro, foi cantado aos quatros cantos que foi uma grande vitória, sendo que não foi. Diversos especialistas disseram, na época, que esse acordo já vinha de muito tempo atrás, se eu não me engano, acho que vinha desde o governo Itamar Franco, até antes disso... E não era favorável ao país. Ele [Bolsonaro] assinou o contrato e veio um representante do governo do Estados Unidos para cá, para o Brasil, dizer que o acordo não poderia ser bom para o país, que não pode sair falando.

5 Em referência ao pronunciamento do Secretário de Comércio dos Estados Unidos, Wilbur Ross, em julho de 2019. Cf. Cagliari (2019). 
Então, o governo recua. Interessante também, mas agora sendo uma tarefa especulativa, foi como coincidiram o recuo do governo brasileiro em relação a esse acordo e os incêndios na Amazônia.

Existe uma outra questão que eu acredito que esteja por trás também: é a questão do submarino nuclear. Ela se refere ao acordo de construção de três submarinos, dois deles convencionais e um deles nuclear, entre Brasil e França. Esse desgaste pode estar subentendido também, além da questão do acordo comercial e da construção da arma nuclear. Para quem não sabe, esse foi um projeto, um acordo desenvolvido nos governos Lula e depois Dilma, segundo o qual Brasil e França iriam desenvolver submarinos utilizando tecnologia nacional, desenvolvendo tecnologia nacional da Marinha, porque foram descobertas as reservas de Pré-Sal e, imediatamente após a descoberta, os Estados Unidos anunciaram a quarta frota naval nos mares sul-americanos, sendo que não há território estadunidense dentro dessa região. Então, acho que tudo isso está envolto em um jogo de interesses, no qual o Brasil se coloca de forma subalterna frente aos Estados Unidos. E ainda existem outras questões para o debate mais adiante...

Pedro Victor: É bom destacar que aqui não é teoria da conspiração, estamos falando com especialistas, pessoas que trabalham, aprofundando estudos acadêmicos em relação a esses temas. Não é isso, Gustavo?

Gustavo Guerreiro: Exatamente. Em relação à fala do Ricupero, que você colocou, de preocupação com a imagem do Brasil, eu pessoalmente não curto muito esse lance da imagem, eu curto mais a realidade, porque a imagem é um reflexo da realidade. A realidade é atroz; a imagem do país, isso [serve] para ilustrar a infinidade de impropérios sendo praticada por esse governo.

Pedro Victor: Bom, e depois dessa declaração do Ricupero, o Bolsonaro já abriu uma nova frente, uma crise agora com o Chile. Para quem não acompanhou esse fato, a ex-presidente do Chile e agora Alta Comissária para Direitos Humanos na ONU, Michele Bachelet, afirmou em entrevista em Genebra, [no] dia 4 de setembro, [que] o espaço democrático no Brasil estava encolhendo. Nas palavras dela, "nos últimos meses vemos uma redução do espaço cívico-democrático, caracterizado por ataques contra defensores 
dos Direitos Humanos e restrições impostas ao trabalho da sociedade civil". A resposta de Jair Bolsonaro foi a de exaltar a ditadura de Augusto Pinochet, que torturou a Michele e assassinou o seu pai, Alberto Bachelet. Autoridades chilenas e brasileiras rechaçaram a fala do presidente.

Professora Débora, esse fato traz uma série de problemas que podem ser analisados pelo Direito Internacional. Quais você pode apontar?

Débora Santana: De acordo com o que foi colocado pela imprensa, a Alta Comissária para Direitos Humanos, Michele Bachelet, deu esse pronunciamento após fazer um estudo sobre o aumento do número de mortos cometidos por policiais. Ela deu esse pronunciamento após esse estudo que foi divulgado...

Pedro Victor: Não foi um ataque gratuito, portanto.

Débora Santana: Não, não houve um ataque direcionado especificamente ao presidente [Bolsonaro]. Na verdade, existe uma crítica em relação à proteção dos Direitos Humanos no Estado brasileiro e, quando ela faz essa crítica, logo em seguida, infelizmente, digamos que diante de um mal contexto, o nosso presidente responde dessa maneira, exaltando a época da ditadura, diretamente atacando o pai da atual Alta Comissária de Direitos Humanos da ONU. O Secretário Geral da ONU, [António Guterres], disse que estava em apoio a Bachelet. Aí vou voltar ao que [eu] havia comentado anteriormente: [isso] estremece e joga até por terra, arruína o que vinha de diplomacia da paz. [Essa diplomacia] nunca se estremeceu, ou foi criticar, ou chegou a entrar em vias com outros Estados. O Brasil faz parte da ONU, desde 1945. Se existe um estudo sobre o Estado brasileiro, não cabe ao presidente [Bolsonaro] atacar pessoalmente uma funcionária da ONU. Então, eu vou repetir, ser redundante mesmo: isso, além de ficar feio, estremece as relações internacionais.

Nós vamos abrir a próxima Assembleia Geral da ONU, mas o que vai acontecer na próxima semana? ${ }^{6}$ O Estado brasileiro vai estar lá, representado por um chefe de Estado que ataca um

6 A Assembleia Geral da Organização das Nações Unidas tem início sempre durante a segunda quinzena de setembro. 
funcionário da ONU. Inclusive, teve uma organização não governamental, cujo nome não recordo, que pediu explicitamente à secretaria da ONU que fizesse retaliações ao presidente pelo seu discurso. Enfim, isso não vai acontecer, porque a ONU pretende que a Assembleia seja pacífica; é uma organização pacífica e isso não deve acontecer, porque não cabe ao secretário fazer esse tipo de retaliação; mas acredito que, certamente, alguns representantes de alguns Estados podem querer se levantar no momento da apresentação do Estado brasileiro. Aí eu volto à fala da professora Mônica: podemos perder um espaço que sempre tivemos, de abrir a Assembleia Geral da ONU. Então, se é um Estado cujo funcionário está fazendo nada mais, nada menos que seu papel, e se é um Estado que já não é mais bem visto dentro da própria Assembleia, sendo bem objetiva, acredito que nós podemos perder esse espaço que sempre tivemos até agora. É assim, de maneira muito objetiva, de imediato: podemos chegar a perder esse espaço certo.

Mônica Martins: Eu queria acrescentar à fala muito interessante da Débora que a ONU tem uma série de fraquezas, que são reconhecidas: não é de hoje que se tenta fazer uma reforma nas Nações Unidas para torná-la mais eficiente. Ela [a ONU] é representante da comunidade internacional, foi criada em 1946 e, de lá para cá, muita coisa mudou: as relações internacionais, o novo sistema, o mundo mudou nesses últimos anos. Quer dizer, algumas das coisas que realmente chamaram a atenção foi o ataque às Torres Gêmeas em 2001.7 A partir daquilo, [o sistema] se transformou em outra coisa. Houve, por exemplo, a emergência de atores que não trabalham com guerra convencional, como o Estado Islâmico e o Boko Haram. Houve ainda as revoluções coloridas, ${ }^{8}$ ou as guerras

7 Em referência ao World Trade Center, em Manhattan, na cidade de Nova York (EUA).

8 "Revoluções coloridas" é a designação atribuída a uma série de manifestações políticasdeoposiçãoa governospolíticosvigentes, ocorridasapartirdosanos2000, que envolveram a derrubada de governos considerados contrários aos Estados Unidos e a sua substituição por governos pró-Ocidente. Estas manifestações têm em comum o uso de ação direta, da resistência não-violenta (de acordo com os seus apoiantes) e de um discurso democratizante, liberalizante e próOcidente. Alguns exemplos são a Revolução Bulldozer, em 2000, na Iugoslávia; a Revolução Rosa, na Geórgia, em 2003; a Revolução Laranja, na Ucrânia, em 2004; e as Jornadas de Junho de 2013, no Brasil. 
híbridas. Quer dizer, [mudou] a forma de se lutar e se guerrear. A ONU foi criada justamente para trazer a paz, para a humanidade não se acabar, logo após a II Guerra Mundial. Enfim, hoje em dia, as formas de guerrear, as formas que a comunidade internacional [tem] de se relacionar mudaram muito. Então, a ONU tem que acompanhar essas transformações; ela tem inúmeras fraquezas, mas ainda é o que de melhor nós temos.

Os Estados Unidos têm sistematicamente tentado boicotar [os acordos internacionais]. Por exemplo, não assinou uma convenção sobre os direitos das mulheres, não assinou outra convenção que fala dos tratados atômicos. Os Estados Unidos têm - ao contrário da tradição do Brasil de apoiar o multilateralismo - uma visão oposta [à da ONU], ele sistematicamente tenta tirar o tapete da ONU, dominar o Conselho de Segurança, ${ }^{9}$ que tem os mesmos cincos países desde que ela foi criada e não se mudou nada. Ele [os EUA] tira recursos, funcionários, não assina determinados tratados, ameaça... Vejo o seguinte: a postura do atual presidente do Brasil é uma postura de subserviência total. Se ele quer atacar um funcionário da ONU, é capaz de dizer "eu não vou na ONU, porque eu não sei [se] ela me representa". Então, ele está exatamente fazendo o jogo.

Débora Santana: ... Norte-americano.

Mônica Martins: Exatamente, do Império dos Estados Unidos, o Império do Caos, da Incoerência. Ele [o presidente Bolsonaro] está fazendo o jogo desse império e não tem nada de soberano nessa postura, não tem soberania. Não sei a qual soberania ele [o presidente brasileiro] está se referindo, porque nacional não é... Só se ele está defendendo a soberania dos Estados Unidos, como defendeu em várias ocasiões, [quando] deu sinais de uma defesa dos interesses, da bandeira, do hino... dos Estados Unidos. Isso absolutamente contraria a nossa tradição. Quer dizer, soberania é uma convenção. Na verdade, nenhum país é soberano. Se cada país fosse soberano e fosse exercer a sua soberania, era uma

9 O Conselho de Segurança das Nações Unidas é composto por 15 membros, sendo 5 permanentes (China, Estados Unidos, França, Reino Unido e Rússia) e mais 10 não permanentes, eleitos anualmente em caráter rotativo e com mandatos de 2 anos. 
anarquia. Acho que a gente está vivendo um momento extremamente delicado, de disputas. É uma grande disputa, inclusive em termos do que significa pertencer às Nações Unidas.

Débora Santana: ... Só complementando a professora Mônica: os Estados Unidos, [ou] não assina, [ou] assina, mas não ratifica alguns tratados de Direitos Humanos. Isso não torna obrigatório, por exemplo, reativar o Tribunal Penal Internacional e outras cortes. Ou seja, nem os norte-americanos podem ser levados [a julgamento] por crimes que já cometeram contra a humanidade como genocídios e agressão. Não podem ser levados ao Tribunal Internacional e, ao mesmo tempo, eles querem controlar a ordem mundial, mas não participam, nem se submetem a ela. Além disso, é a questão da falha da ONU: os Estados Unidos, muitas vezes, passam por cima de decisões do próprio Conselho de Segurança, como aconteceu no Iraque, alegando legítima defesa preventiva.

Concordo plenamente quando ela [a professora Mônica] pergunta, que soberania é essa que nós vamos defender? É a soberania do que achamos bonito e a qual nós queremos ser iguais. Nós voltamos a [desempenhar] um papel de submissão, porque nós, brasileiros, devemos conhecer quem são os Estados Unidos. É esse papel que nós queremos? Essa é a aproximação que nós queremos? O que nós fizemos? E aí eu cito Fernando Henrique Cardoso, [em cujo governo], por mais que [fosse] de direita, nós não tínhamos essa subserviência que apresentamos em nove meses de governo [Bolsonaro]. Então, o que fizemos de Fernando Henrique até agora? Nós queremos voltar ao papel [de subserviência], é isso que nós queremos? Que país é esse que nós estamos voltando a ser, ao nos alinhar [aos EUA]? Então, é preciso que nós, brasileiros, conheçamos o que queremos para o Brasil.

Pedro Victor: Fazendo um histórico rápido: o primeiro atrito [na diplomacia brasileira de] que podemos falar é a retirada dos médicos cubanos do Programa Mais Médicos; ${ }^{10}$ depois houve a

10 O Programa Mais Médicos foi criado por meio da Medida Provisória $n^{\circ} 621$ e regulamentado pela Lei $n^{\circ} 12.871$, ambas em 2013, durante o governo de Dilma Rousseff, com o objetivo de suprir a carência de médicos nos municípios do interior e nas periferias das grandes cidades do Brasil. Para saber mais, ver Programa... (2015). 
questão da mudança da embaixada brasileira [de Tel Aviv] para Jerusalém [em Israel], que seria um problema em si, já que também é um território que os palestinos reivindicam. Os países árabes, então, se mobilizaram para boicotar a importação da carne brasileira. Depois, houve o risco de conflito com a Venezuela, um país vizinho; os atritos com Alemanha e Finlândia, que tiraram dinheiro do fundo Amazônia, que ajudava, inclusive, com mecanismos de vigilância e proteção ambiental; [os atritos com] a França, [pois] o próprio presidente francês fez uma declaração sobre os vários mal entendidos com o governo do presidente Jair Bolsonaro.

Primeiro, tem a ver com o que Gustavo falou: relação UE e Mercosul. Esse acordo de cooperação entre UE e Mercosul é uma das coisas com que o presidente havia se comprometido. [Ele iria] fazer de tudo para preservar o meio ambiente e, poucos dias depois, vimos que não era coerente, já que ele demitiu o [diretor Ricardo Galvão do] INPE. Essa é a visão do presidente francês [Manoel Macron]. Depois, o chanceler [Ernesto Araújo] quis se reunir [com a França] e ele [Bolsonaro] desmarcou "para cortar o cabelo", nas palavras do presidente francês. Depois, aquele problema gerado pela internet: ele [Bolsonaro] riu de um comentário depreciativo sobre a esposa do presidente francês [e] foi corroborado recentemente pelo [ministro da Economia] Paulo Guedes, que concordou com a visão do presidente [brasileiro] sobre [o fato]. Na Argentina, o presidente Bolsonaro se pronunciou sobre o risco de o candidato apoiado pela Cristina Kirchner ser eleito e o apoio dele ao [Maurício] Macri impactou de maneira negativa. Não é isso, professora Mônica?

Mônica Martins: Exato.

Pedro Victor: Você poderia explicar para a gente o que aconteceu na Argentina?

Mônica Martins: Bem... na Argentina, temos um convênio entre o Observatório das Nacionalidades da UECE e a Universidade Nacional da Patagônia Astral, que fica fora do eixo de Buenos Aires. Somos duas universidades de regiões afastadas e temos um convênio para estudar, exatamente, as nacionalidades. Então, nossa aproximação com os pesquisadores argentinos é grande e eles têm nos colocado a par da mobilização constante da 
população [argentina], faz um tempo. A população argentina não aceita os cortes, o neoliberalismo que foi implantado pelo governo Macri e que tem causado muitos danos à maioria do povo argentino. Essa frente de luta está fazendo com que as últimas pesquisas apontem a vitória do candidato que se opõe ao Macri.

A aproximação entre Brasil e Argentina sempre foi bastante tumultuada. Contudo, na época em que foi acertada a construção do Mercosul, aqui era o governo do FHC e a tendência [desde então] tem sido de uma aproximação não só comercial, mas também nos aspectos culturais e sociais [dos dois países]. É uma aproximação maior mesmo em vários aspectos e essa aproximação foi rompida quando o nosso presidente [Bolsonaro] fez uma crítica ao atual candidato que está à frente nas pesquisas, se pronunciando intrometidamente em um assunto que não lhe diz respeito.

Pedro Victor: Como vocês avaliam isso? É normal que os presidentes torçam para que outros candidatos ganhem?

Mônica Martins: Não, não.

Débora Santana: Ele [Bolsonaro] está, inclusive, ferindo um dos princípios do Direito Internacional, o de não intervenção em assuntos internos de outros Estados. Então, da mesma forma que ele não quer intervenção na nossa soberania sobre a Amazônia, ele também não deve interferir em assuntos exclusivamente internos de outro Estado.

Gustavo Guerreiro: Inclusive, Débora, a tradição da diplomacia brasileira remonta a Rui Barbosa, quando ele participou, em 1907, da Convenção de Haia sobre uma resolução pacífica de contencioso internacional. A diplomacia brasileira ganhou destaque mundial quando Rui Barbosa defendeu a ideia de que todos os Estados são iguais - obviamente não são iguais, cada um tem suas particularidades -, diante da comunidade internacional. Então, a diplomacia brasileira é muito pautada nesse princípio e ele [Rui Barbosa] tem um protagonismo muito grande, com Osvaldo Aranha, quando ele articulou a construção do Estado de Israel de forma relativamente pacífica. Até hoje, não se conseguiu criar um Estado na Palestina, mas ele teve um papel determinante.

Débora Santana: Ele presidiu, né... 
Gustavo Guerreiro: Ele presidiu, exato. Então, por isso também que o Brasil sempre abre as Assembleias Nacionais da ONU. Quando Bolsonaro faz uma fala dessas, ele desrespeita não só a soberania do Estado argentino, mas a vontade popular.

Pedro Victor: E como vocês avaliam a visão do povo argentino sobre o presidente Jair Bolsonaro?

Mônica Martins: A grande maioria da população protesta contra ele [Bolsonaro]. Quando ele esteve lá em Buenos Aires, antes desse pronunciamento, inclusive, lembro muito bem os bonecos que fizeram e as manifestações contra o Bolsonaro. Ao que dizem, na Argentina, a população está 24 horas na rua. Não sai da rua. É uma mobilização permanente, não casual. "Vamos para a praça dia 10, às 8 horas da manhã, e saímos ao meio dia", não é assim. É uma mobilização permanente e cotidiana, dentro de casa, na rua, dentro das empresas. E o Bolsonaro é, realmente, considerado persona non grata na Argentina, desde antes do depoimento dele.

Tem um princípio também da autodeterminação dos povos. Esse é um dos princípios básicos do Direito Internacional. A fala dele [de Bolsonaro], a postura dele, é exatamente de alguém que não tem capacidade, não tem o menor conhecimento, não tem a capacidade de ser um estadista.

Gustavo Guerreiro: Inclusive, Mônica, quando se fala em autodeterminação, também se tem que citar internamente a questão dos povos indígenas. Existe uma convenção internacional, a Convenção 169 [da Organização Internacional do Trabalho, sobre povos indígenas e tribais], que prevê o respeito à diversidade cultural dos povos indígenas. É para os Estados nacionais respeitarem. O que ele [Bolsonaro] faz para fora, ele faz para dentro também.

A questão da interferência não se limita só à Argentina, você tem de citar, principalmente, o caso da Venezuela. Esse governo defende uma intervenção bélica em assuntos internos da Venezuela. Quer queira, quer não - embora não seja um governo dos sonhos de muita gente, está longe disso -, é um assunto interno deles [dos venezuelanos], que eles têm que resolver. Hoje mesmo eu li uma matéria na Folha de São Paulo [em que mencionavam] "o ditador Nicolás Maduro". Nicolás Maduro não é 
um ditador, ele foi eleito. Embora o processo democrático venezuelano seja um processo, de certa forma, viciado, em que haja corrupção, como no Brasil, é um assunto deles.

E eu queria até lembrar que, de ontem para hoje, saiu uma matéria dizendo que o governo dos Estados Unidos está solicitando ao Brasil que faça uma representação junto à ONU acerca de violações dos Direitos Humanos na Venezuela. São instrumentos que a Casa Branca utilizava para denunciar governos frágeis, como era o Paraguai e a Guatemala. Isso serve para eles [os americanos] falarem o seguinte: "olha aí, eles próprios [os brasileiros] estão denunciando, então nós temos legitimidade de invadir, de ocupar em nome dos Direitos Humanos", como eles [os americanos] têm feito em relação ao TIAR, ${ }^{11}$ que é um tratado de intervenção recíproca da II Guerra Mundial, para justificar uma invasão bélica ao território venezuelano. Então, o governo brasileiro se presta a esse papel de submissão vassala ao imperialismo. E é interessante, Débora, porque ele está sendo demandado para denunciar Direitos Humanos na Venezuela. Veja bem: o governo Bolsonaro, que exalta torturador, exalta ditadura....

Débora Santana: Inclusive, entendi no discurso dele [Bolsonaro] que quem não tem nada para fazer deve ir para a cadeira de Direitos Humanos da ONU. Então, que legitimidade ele teria de denunciar a Venezuela por violação dos Direitos Humanos dentro da ONU, se nem ele mesmo acredita nesse conceito?

Gustavo Guerreiro: Um poço de contradições. E outra: se essa denúncia demandada ao Brasil for aceita, quem fica com o ônus político não é a Casa Branca, vai ser o Brasil.

Pedro Victor: Bem, sobre essas declarações do Bolsonaro sobre a ex-presidente do Chile, Michele Bachelet, e sobre o seu

11 O Tratado Interamericano de Assistência Recíproca (TIAR) foi assinado pelas repúblicas americanas na Conferência do Rio de Janeiro, em 1947. Esse tratado - de defesa hemisférica - "estabelecia basicamente que 'um ataque armado por qualquer Estado contra um Estado [no continente] americano será considerado como um ataque contra todos os Estados americanos', ao mesmo tempo que definia os princípios, obrigações e mecanismos que deveriam ser postos em ação em caso de necessidade. O tratado procurava dar um formato permanente às afirmações de solidariedade hemisférica estabelecidas em encontros interamericanos anteriores, especialmente na Conferência do México, dois anos antes (1945)" (TRATADO..., 2020). 
pai, assassinado pela ditadura de Pinochet, é bom destacar a discordância do atual presidente [de Israel] Sebastian Pinheiro, que é de direita. Inclusive Bolsonaro, assim que assumiu [o governo], programou três grandes viagens internacionais para Israel, Estados Unidos e Chile. Por que ele chegou nesses três países como grandes parceiros internacionais e por que o presidente do Chile, que é de direita, repudiou as falas do Bolsonaro?

Gustavo Guerreiro: Porque o Chile fez o dever de casa em relação à apuração dos crimes da ditadura e nós não fizemos esse papel aqui. Houve uma Comissão Nacional da Verdade $(\mathrm{CNV})^{12} \mathrm{e}$ foi passado pano. Aquela política conciliatória não passou, "não vamos remexer em ferida do passado". Nós não resolvemos esse lado importante da nossa história e as arestas estão para fora.

Débora Santana: Inclusive, a CNV nem poderia ter o papel de punir, pois nós temos hoje a Lei de Anistia, ${ }^{13}$ que foi julgada e admitida pelo Supremo Tribunal Federal. Nisso, começa sem punir os responsáveis pelos crimes da época da ditadura militar. Eu sinto aqui, claramente, os dois lados: a Lei de Anistia anistiou os dois lados da situação e, além de ser uma petição conciliatória, nós não conseguimos [que] os militares envolvidos nesse processo contassem a verdade. Poucos foram realmente os testemunhos que identificaram os fatos e os responsáveis. Que política realmente foi trazida pela CNV? Ela foi importante? Ela foi, mas não conseguimos ir muito adiante. Para que a gente tenha hoje um chefe do executivo eleito democraticamente pela maioria da população e que exalta, em seu discurso, a ditadura como um processo, digamos, normal dentro da história brasileira, isso é gravíssimo! Alemanha, Chile e diversos países trabalham com a história viva e nós não. Queremos repetir os erros do passado. E, no Brasil, temos uma exaltação pelo passado, parece que desconhecemos a nossa história; para muitos, não houve ditadura.

12 A Comissão Nacional da Verdade (CNV) foi criada pela Lei 12528/2011 e instituída em 16 de maio de 2012. Ela tem por finalidade apurar graves violações de Direitos Humanos ocorridas entre 18 de setembro de 1946 e 5 de outubro de 1988. Para saber mais, ver CNV (2020).

13 Em referência à Lei 6.683, de 28 de agosto de 1979. 
Pedro Victor: Professora Débora, diante desse histórico que já acumulamos no atual governo, em relação a Cuba, aos países árabes, a Venezuela, a atritos com Alemanha, Finlândia e França, a interferências no processo eleitoral da Argentina e até com o Chile, que é um dos três parceiros internacionais, há um risco do Brasil se isolar internacionalmente?

Débora Martins: Na perspectiva atual na qual estamos caminhando, eu sinto que sim. Contudo, esse isolamento seria para se associar apenas ao grande ídolo, no momento, do governo [brasileiro] que seriam os Estados Unidos. Então, sim, parece que estamos quebrando tudo que construímos anteriormente, relacionamentos com diversos países e mais ainda, com os países do Mercosul, que são os nossos parceiros. O Chile não é membro do Mercosul, mas [é] um Estado associado. Então, nós estamos estremecendo nossas relações e volto novamente à pauta desse governo: a meta principal é a economia; se continuarmos nesse caminho, vamos nos isolar economicamente e o que representaria para nós estarmos associados apenas ao Estados Unidos?

Pedro Victor: Nós temos a participação da ouvinte Socorro Carvalho, que fala do [bairro] Henrique Jorge e ela comenta o seguinte: "é muito bom ter os pés na realidade, mas não perder a esperança. O que podemos esperar da fala do presidente na ONU e o que podemos fazer enquanto povo?"

Mônica Martins: Acho que não podemos perder a esperança enquanto povo. Nós temos que entender que a política externa é tão fundamental quanto qualquer outra política. Ela está no nosso dia a dia, não é alguma coisa distante, de diplomata ou de militar. A política externa tem que ser praticada, tem que ser cuidada. Ela afeta o que a gente come, afeta os nossos filhos na escola. Então, no Ceará - pois nós estamos em um ponto geopolítico privilegiado, estamos perto da Europa, perto dos Estados Unidos e recebemos muitos estrangeiros -, temos uma tradição de abertura...

Pedro Victor: ... Estamos perto da África...

Mônica Martins: ... Pertíssimo da África. Então, acho fundamental, enquanto povo brasileiro, a gente começar a discutir e trazer para o nosso cotidiano as decisões da política internacional. 
Tem uma comissão no Congresso, tem uma comissão no Senado, que discute a questão internacional... ${ }^{14}$

Pedro Victor: As pessoas não levam muito em conta, por exemplo, nas propostas de campanha, durante as eleições, as relações internacionais.

Mônica Martins: Exatamente! Nós elegemos deputados e senadores. Quem vai aprovar, ou não, a indicação do [Eduardo Bolsonaro] filho do presidente para a embaixada nos Estados Unidos é essa comissão de relações exteriores... Mas a gente não tem preocupação, a gente não acompanha [as questões internacionais do Brasil]. Acho que é hora de a gente incluir [essa pauta] nas nossas lutas pela educação, pela água, pelo transporte coletivo, pela saúde... Discutir as questões internacionais e como elas refletem no nosso dia a dia.

Pedro Victor: E o que vocês esperam da fala do presidente Jair Bolsonaro para a abertura da Assembleia Geral da ONU?

Mônica Martins: Eu não espero absolutamente nada.

Gustavo Guerreiro: É, eu acho que ele vai inventar uma nova internação para não participar da Assembleia [na ONU]... Eu estou brincando! Também não tenho esperanças que ele vá fazer uma fala minimamente razoável, até mesmo porque o nosso embaixador, o nosso ministro das Relações internacionais [Ernesto Araújo] foi para Washington [D.C.], na semana passada, para conversar com Steve Benon, para saber o que dizer na abertura da Assembleia. Então, o que a gente pode esperar?

Pedro Victor: Bom, na semana passada, governadores dos nove estados do Nordeste brasileiro anunciaram a articulação de uma frente diplomática em busca de investimentos internacionais. O governador da Bahia, Rui Costa, declarou ao Portal de Notícias Uol que o plano é propor aos países europeus que invistam na região os recursos rejeitados pelo presidente. "Nós queremos dizer que existe um Brasil diferente que é o de governantes que valorizam o meio ambiente, a diversidade humana, mostrar que o

14 Em referência à Comissão de Relações Exteriores e de Defesa Nacional no Senado e à Comissão de Relações Exteriores e de Defesa Nacional no Congresso Federal. 
Brasil não é essa coisa temporária que ocupa o Governo Federal", disse. O grupo planeja um giro pela Europa na segunda quinzena de novembro [de 2019]. O que lhes parece esse movimento independente dos governadores? Quais os efeitos diplomáticos dessa iniciativa?

Mônica Martins: Eu acho fantástico. Já havia uma preocupação grande com a ruptura do convênio com os médicos cubanos. O Nordeste e o Norte foram grandemente afetados, porque os médicos se dedicavam às populações mais distantes, aos povoados mais inacessíveis. Eles iam para lá, tanto aqui no Nordeste, como no Norte. Então, parece que há uma intenção dos nove governadores de voltar a fazer um convênio diretamente com Cuba e agora há essa notícia fantástica de que eles vão fazer um giro pela Europa, tentar trazer recursos para garantir a nossa sobrevivência enquanto região nordeste. Na verdade, demos uma grande lição ao Brasil inteiro, quando nós votamos contra o atual governo. A gente busca parcerias e há uma diplomacia feita por cidades...

Débora Santana: A federativa? É porque alguns Estados [federativos] permitem que estados e municípios assinem e ratifiquem tratados. Eles têm essa autonomia. Eles [os governadores desses estados e municípios] podem falar em nome do Estado. Não é o caso Brasil; aqui não temos [isso] por conta da Constituição [Federal de 1988].

Mônica Martins: Exatamente. Ao que tudo indica, a China e os países árabes também estariam dispostos a assinar convênios [com o Nordeste]. O Nordeste tem um grande potencial da carne que eles preferem, que é a carne de criação. É o nosso bode, o nosso carneiro... Lembro da época em que Eudoro Santana era o Secretário de Agricultura e Reforma Agrária, no primeiro governo do Tasso Jereissati, e foi assinado um grande convênio com oito países árabes que compravam de produtores de caprinocultura do Ceará, os quais receberam todo o incentivo para criar suas cabrinhas e seus bodes dentro daquilo que os árabes queriam. Foi um sucesso!

Pedro Victor: Tendo o processo de sacrifício, de abatimento diferenciado... 
Mônica Martins: ... Diferenciado... E acho que é a grande possibilidade de inovar e ter uma diplomacia que garanta que os nossos votos não sejam perdidos, que a gente se fortaleça como região.

Pedro Victor: Já estamos no finalzinho do programa e quero apenas pedir uns comentários rápidos. Então, professora Débora: estranhei muito esses comentários que pautavam as esposas dos presidentes da França e do Brasil, de nações muito importantes, no mundo inteiro, que recebem destaque internacional. Como isso pode abalar as relações Brasil - França? Como isso pode surtir efeito, por exemplo, na economia brasileira?

Débora Santana: Esse tipo de comentário dento da história da diplomacia brasileira, eu jamais ouvi falar. Então, pela primeira vez na história, nós temos esse tipo de farpa e crise em relação a discursos e relativamente às esposas. Até vamos colocar o pai da ex-presidente, como no caso do Chile. A França é um grande parceiro do Brasil e isso já vem de anos; é um parceiro econômico e também pelo contexto da UE, porque Alemanha e França são realmente os países que comandam a UE. Então, diplomaticamente, isso estremece as nossas relações que são, basicamente, de caráter pacífico. Economicamente, eu não vejo, de forma objetiva, como isso iria nos atingir. A longo prazo, alguns discursos irresponsáveis que sejam reiterados pelo presidente... isso estremece, pode haver um bloqueio da carne brasileira, pode haver um bloqueio de outro produto brasileiro por parte da França e da própria UE. Eles poderão achar, por exemplo, que a questão da Amazônia é um motivo para, digamos, suspender a [importação da] carne brasileira. Isso é obvio pela utilização de agrotóxicos que foram aprovados aqui no Brasil, mas que a UE trata com política justamente inversa. Então, não é que essa fala vá diretamente repercutir na economia, na suspensão de trocas comerciais, mas o reiterado discurso irresponsável pode, sim, afetar a economia. Aí é muito fácil para qualquer Estado achar um defeitinho no Brasil e, por conta desse defeito, não mais importarem a carne brasileira.

Só lembrando que essa questão ambiental é uma questão que é pautada na maioria dos acordos comercias. Dentro da OMC, 
tem-se o acordo GATT, ${ }^{15}$ um exercício de comércio multilateral. Ou seja, o Estado pode suspender [o comércio com outro Estado], por conta da violação da proteção da fauna e da flora. Isso no acordo da UE, no acordo do Mercosul, nos acordos de cooperação com os outros Estados. Então, a pauta ambiental é uma pauta presente em praticamente todos os acordos comerciais e se pode encontrar um motivo que venha a suspender a [compra da] carne brasileira.

Pedro Victor: Antes de encerrar, queria pedir então para a professora Mônica Martins e para Gustavo Guerreiro que eles falem do Observatório das Nacionalidade e da revista Tensões Mundiais.

Mônica Martins: O grupo de pesquisa do Observatório das Nacionalidade existe desde 2001. Foi criado aqui na Universidade Federal do Ceará, no Departamento de Sociologia. Depois, nós mudamos para a UECE, onde estamos até hoje. Integram o grupo militares, intelectuais, professores, estudantes e artistas. É um grupo multifacetado. Quem quiser ingressar, é um prazer enorme receber.

Gustavo Guerreiro: Tensões Mundiais é uma revista reconhecida internacionalmente. Estamos classificados entre as melhores revistas do país e o site, para quem quiser acessar na íntegra todos os artigos, é revistas. uece.br $\backslash$ tensoesmundais.

Pedro Victor: Para o ouvinte que não pode anotar, vamos deixar aqui esse link disponível no twitter @universitariafm. Bom, quero me despedir e agradecer a presença da professora Mônica Martins.

Mônica Martins: Eu que agradeço.

Pedro Victor: ... Agradecer a presença da professora Débora Santana.

Débora Santana: Também agradeço e ótimo dia a todos.

Pedro Victor: ... E agradecer a presença do pesquisador Gustavo Guerreiro.

Gustavo Guerreiro: Também agradeço e faço a provocação para que a gente continue esse assunto em outros programas.

15 GATT é a sigla correspondente a General Agreement on Tariffs and Trade, que, traduzido para o português, é o Acordo Geral de Tarifas e Comércio. Essa sigla representa uma série de acordos de comércio internacional destinados a promover a redução de obstáculos às trocas entre os países parceiros, em particular as tarifas e taxas aduaneiras entre os membros (O QUE..., 2020). 


\section{Referências}

CAGLIARI, A. Acordo EUA-Brasil depende de desfecho com UE, diz secretário de comércio americano. Folha de S. Paulo, São Paulo, 30 jul. 2019. Disponível em: https://www1.folha.uol.com.br/mercado/2019/07/ acordo-eua-brasil-depende-de-desfecho-com-eu-diz-secretario-decomercio-americano.shtml. Acesso em: 13 out. 2020.

CNV. Comissão Nacional da Verdade, [online], 2020. Disponível em: http://cnv.memoriasreveladas.gov.br/institucional-acesso-informacao/ a-cnv.html. Acesso em: 30 set. 2020.

O QUE é o GATT? Fazcomex, [online], 2002. Disponível em: www. fazcomex.com.br/blog/o-que-e-o-gatt/. Acesso em: 30 set. 2020.

PROGRAMA Mais Médicos - Dois anos: Mais Saúde para os Brasileiros. Ministério da Saúde, [online], 2015. Disponível em: http://maismedicos. gov.br/images/PDF/Livro_2_Anos_Mais_Medicos_Ministerio_da_ Saude_2015.pdf. Acesso em: 30 set. 2020.

TRATADO Interamericano de Assistência Recíproca (TIAR). FGV-CPDOC, [online], 2020. Disponível em: www.fgv.br/cpdoc/acervo/dicionarios/ verbete-tematico/tratado-interamericano-de-assistencia-reciproca-tiar. Acesso em: 30 set. 2020. 